\title{
PERANCANGAN KEMASAN MURIA BATIK KUDUS UNTUK MEMPERKENALKAN KEBUDAYAAN LOKAL KOTA KUDUS
}

\author{
Indah Sulistyorini ${ }^{1}$, Birmanti Setia Utami ${ }^{2}$ \\ 1,2Program Studi Desain Komunikasi Visual, Fakultas Teknologi Informasi, \\ Universitas Kristen Satya Wacana \\ ienlisty@gmail.com ${ }^{1}$, birmanti@gmail.com²
}

\begin{abstract}
Abstrak
Batik Kudus merupakan salah satu ragam Batik yang ada di Indonesia. Setelah sempat menghilang, Muria Batik Kudus kembali memunculkan ragam batik Kudus dengan motif-motif kebudayaan di Kudus. Untuk menguatkan citra eksklusif dan kebutuhan distribusi produk, terutama dengan bergabungnya Indonesia dalam Masyarakat Ekonomi Asean dan budaya belanja online, produk Muria Batik Kudus memerlukan kemasan baru yang dapat menjawab kebutuhan tersebut. Kemasan Muria Batik yang baru diharapkan dapat menunjukkan eksklusivitas produk dan mengenalkan kebudayaan lokal kota Kudus kepada para konsumennya. Metode penelitian deskriptif kualitatif digunakan dalam pengambilan data dengan wawancara agar mendapatkan informasi yang mendalam. Perancangan Kemasan Muria Batik Kudus sudah diujikan dan didapatkan hasil bahwa perancangan kemasan dapat menunjukkan eksklusivitas produk batik dan dapat mengenalkan kebudayaan yang ada di kota Kudus melalui katalog yang ada dalam kemasan.
\end{abstract}

Kata Kunci: desain kemasan, kebudayaan lokal, batik Kudus

\begin{abstract}
Batik Kudus is one of the Indonesian batik varieties. After disappearing for decades, Muria Batik Kudus bring back this variety of batik with Kudus's cultural pattern. To strengthen the exclusive image of this product alongside the needs of product distribution, especially with the emergence of e-commerce and Asean Economic Community in Indonesia, Muria Batik Kudus need a packaging that could answer those needs. The new packaging of Muria Batik is expected to show exclusivity of the products and introduce Kudus local culture to customers. The research uses descriptive and qualitative data by interviewing sources in order to get information. The packaging of Muria Batik Kudus was tested and the result showed that the packaging design shows the exclusive image of the product which also introduces Kudus's local culture with a catalogue inside the packaging.
\end{abstract}

Keywords: packaging design, local culture, batik Kudus 


\section{PENDAHULUAN}

Batik Indonesia begitu kaya dan memiliki kekhasan di setiap daerah dan telah ditetapkan oleh UNESCO sebagai warisan budaya dunia asli Indonesia pada tanggal 2 oktober 2009. Semenjak ditetapkan, setiap tanggal 2 oktober diperingati sebagai "Hari Batik" di Indonesia (Wulandari, 2011: 7). Secara etimologi kata batik berasal dari bahasa Jawa, "amba" yang berarti lebar, luas, kain dan "titik" yang berarti titik atau matik yang memiliki arti membuat titik. Kata tersebut kemudian berkembang menjadi istilah "batik" yang berarti menghubungkan titik-titik menjadi gambar tertentu pada kain yang luas atau lebar. Batik juga mempunyai pengertian segala sesuatu yang berhubungan dengan membuat titik-titik tertentu pada kain mori. Dalam bahasa Jawa "Batik" ditulis dengan "bathik" mengacu pada huruf Jawa "tha" yang menunjukkan bahwa batik adalah batik rangkaian dari titik-titik yang membentuk gambaran tertentu. Batik identik dengan suatu proses dari mulai penggambaran motif hingga pelorodan. Salah satu ciri khas batik adalah cara penggambaran motif pada kain yang menggunakan proses pemalaman yaitu menggoreskan malam yang ditempatkan pada wadah bernama canting dan cap (Wulandari, 2011: 4).

Salah satu kekayaan batik di Indonesia terdapat pada batik Kudus. Dahulu pada tahun 1935 batik ini muncul sebagai batik tulis yang dikenal batik Nyonya atau batik Saudagar yang mempunyai ciri khas kehalusan dan kerumitan isen-isen pada kainnya. Isen-isen merupakan aneka corak pengisi latar kain dan bidang-bidang kosong corak batik (Wulandari, 2011: 105). Batik Kudus sudah mulai ada pada tahun 1935 dan berkembang pesat sampai tahun 1970. Corak dan motif batik Kudus sangat beragam karena pada masa itu pengrajin batik Kudus ada yang dari etnis keturunan tiongkok dan pengrajin penduduk asli atau pribumi. Corak batik Kudus cenderung termasuk batik pesisiran dan memiliki kemiripan dengan batik Pekalongan dan Lasem karena secara geografis letak daerah tersebut berdekatan. Batik Kudus yang dibuat oleh kalangan menengah ke atas, motif yang dibuat coraknya lebih ke arah perpaduan antara batik pesisir dan batik mataraman (warna sogan). Batik Kudus yang dibuat oleh pengrajin asli Kudus atau pribumi dipengaruhi oleh budaya sekitar dan coraknya juga dipengaruhi batik pesisiran. Motif yang dibuat mempunyai arti ataupun kegunaan misalnya untuk acara akad nikah ada corak Kudusan seperti busana kelir burung merak dan motif yang bernafaskan budaya Islam atau motif kaligrafi Islam. Motif yang bernafaskan kaligrafi karena dipengaruhi sejarah walisongo yang berada di Kudus yaitu Sunan Kudus (Syekh Dja'far Shodiq) dan Sunan Muria (Raden Umar Said), corak yang bernafaskan Islam karena pengrajin batik banyak berkembang di sekitar wilayah Sunan Kudus atau dikenal dengan Kudus Kulon.

Pada penghujung tahun 1980 Batik Kudus mengalami kemunduran, banyak pengrajin Kudus yang mengalami gulung tikar dan keberadaan Batik Kudus tergusur oleh industri kretek di kota Kudus. Selama 20 tahun kota Kudus lebih dikenal sebagai kota industri kretek setelah eksistensi batik Kudus mulai tergusur, bahkan banyak orang yang tak yakin bahwa Kudus memiliki tradisi batik. Hanya generasi tua dan pecinta batik yang mengetahui sejarah batik Kudus. 
Pada tahun 2005 salah satu pengrajin batik Kudus kontemporer sekaligus pemilik Muria Batik Kudus, Ibu Yuli Astuti mulai mengembangkan batik Kudus kembali. Motif yang terkandung di dalam Muria Batik Kudus mengandung makna historikal budaya lokal kota Kudus. Usaha yang dibuat oleh lbu Yuli ini adalah untuk tetap mempertahankan dan melestarikan keberadaan batik Kudus agar tetap memiliki eksistensi di tengah masyarakat.

Berdasarkan wawancara dengan Ibu Yuli, produk batik tulis klasik yang ditujukan untuk kelompok sosial ekonomi kelas atas membutuhkan kemasan baru yang dapat menunjukkan eksklusivitas produk sekaligus mengenalkan kebudayaan yang ada di Kudus pada konsumen. Kebutuhan pengemasan ini didasari oleh berkembangnya budaya belanja online sehingga menuntut Muria Batik Kudus untuk meredesain kemasannya sehingga dapat mengakomodir kebutuhan pembeli online. Selain itu, berkaca pada meningkatnya pemberdayaan UMKM di tahun 2015 dibandingkan tahun 2014 sebanyak 1,8\% (Edris, 2006). Pemerintah kota Kudus mendorong para pelaku UMKM untuk tidak hanya meningkatkan kualitas produk tetapi juga meningkatkan kualitas pengemasan produk, terutama dengan masuknya Indonesia ke dalam Masyarakat Ekonomi Asean. Pengemasan produk yang baik dan menarik akan menarik minat calon konsumen untuk membeli produk.

Pengemasan adalah aktivitas merancang dan memproduksi kemasan atau pembungkus untuk produk. Biasanya fungsi utama dari kemasan adalah untuk menjaga produk (Kotler, 2009: 27), namun sekarang kemasan menjadi faktor yang cukup penting sebagai alat pemasaran (Rangkuti, 2005: 132). Pengemasan yang mengangkat produk budaya lokal sudah pernah dilakukan oleh Crisnawati (2013) yang mengangkat desain kemasan kerajinan di "Ria Batik" Solo. Selanjutnya Rahardjo \& Pramusita (2016) meninjau tampilan visual desain kemasan Roti Murni di Yogjakarta untuk mengetahui latar belakang desain kemasan Roti Murni yang sudah lama tidak mengalami perubahan dan meninjau kemasan kardus Roti Murni dengan teori kemasan Desain Komunikasi Visual. Ratnasari (2012) dalam penelitiannya juga mengungkapkan penciptaan produk yang mengusung arti budaya kearifan lokal harus digali kembali, dikembangkan dan ditelusuri, serta dianalisis dalam berbagai aspek kemudian diinovasikan sebagai bentuk dari karya kreatif yang tinggi dan dapat bersaing di dunia global. Berdasarkan ketiga penelitian tersebut, didapatkan bahwa kemasan dapat bermanfaat sebagai pelindung produk dan dapat membuat produk mudah dikenali.

Penelitian mengenai perancangan kemasan Muria Batik diharapkan tidak hanya melindungi dan mengenalkan produknya, tetapi juga dapat menunjukkan citra eksklusif produk dan mengenalkan kebudayaan kota Kudus. Perancangan kemasan yang sesuai dengan produk dan dapat menjawab kebutuhan produk sesuai tuntutan jaman merupakan salah satu cara pengembangan Indonesia kreatif. Perancangan kemasan ini juga menjadi media untuk menunjang nilai jual Muria Batik Kudus dan media untuk memperkenalkan kebudayaan lokal Kudus. 


\section{METODE PENELITIAN}

Metode penelitian yang digunakan adalah metode deskriptif kualitatif, karena dalam pengambilan data diperlukan wawancara dengan narasumber agar mendapatkan informasi yang mendalam. Pendekatan kualitatif bersifat fleksibel dan berubah-ubah sesuai dengan kondisi lapangan dengan mengambil data berupa wawancara (Sarwono, 2007: 95).

Tahapan perancangan dalam penelitian ini menerapkan linear strategy atau strategi garis lurus yang menempatkan ukuran logis pada tahapan yang sederhana dan relatif mudah dipahami komponennya (Sarwono, 2007: 28). Tahapan penelitian dengan linear strategy pada penelitian ini dapat dilihat di bawah ini.

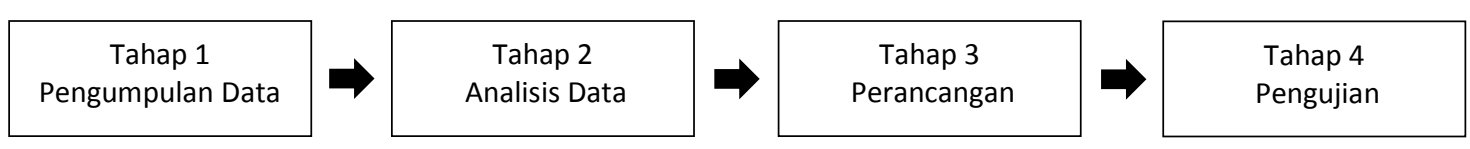

Gambar 1. Linear Strategy

[Sumber : Sarwono, 2007]

Berdasarkan bagan diatas, linear strategy terbagi menjadi 4 tahapan yaitu tahap pengumpulan data, tahap analisis data, tahap perancangan dan tahap pengujian. Tahapan pengumpulan data dilakukan dengan wawancara kepada pemilik Muria Batik Kudus, observasi pada tempat batik dan event-event pameran yang diikuti, dan studi pustaka yang lain seperti dari buku maupun berita-berita seputar Batik Muria Kudus sebagai data penunjang untuk penelitian ini. Tahap analisis data dilakukan dengan menganalisis data menggunakan analisis SWOT (Strength, Weakness, Opportunities, Threats) dari tahapan pengumpulan data kemudian dijadikan sebagai acuan untuk masuk ke tahapan selanjutnya. Tahapan selanjutnya adalah tahapan perancangan, dalam tahapan perancangan ini terbagi menjadi beberapa bagian yakni pembuatan konsep, perancangan kemasan, perancangan katalog serta hasil perancangan kemasan dan katalog. Tahapan selanjutnya adalah tahapan pengujian, pengujian dilakukan kepada pemilik batik, desainer kemasan dan responden selaku target konsumen dari Muria Batik Kudus.

\section{HASIL DAN PEMBAHASAN}

\subsection{Tahap Pengumpulan Data}

Tahap pertama yaitu pengumpulan data adalah tahapan awal dalam perancangan Kemasan Muria Batik Kudus. Pengumpulan data dilakukan dengan cara wawancara dengan Ibu Yuli Astuti selaku pemilik dan pengrajin batik Muria Kudus. Batik Kudus mulai diperkenalkan kembali oleh Ibu Yuli Astuti sejak tahun 2005 melalui brand Muria Batik Kudus. Muria Batik Kudus merupakan sebuah perusahaan sekaligus brand yang memproduksi batik di kota Kudus. Logo yang dimiliki oleh Muria Batik Kudus merupakan perpaduan antara logogram dan logotype. Logo ini ada sejak awal Muria Batik berdiri, yakni pada tahun 2005. 


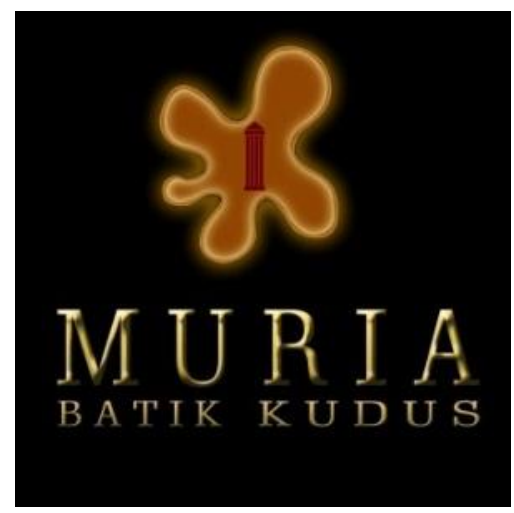

Gambar 2. Logo Muria Batik Kudus

[Sumber: Dokumentasi Penulis]

Selama puluhan tahun batik Kudus mengalami kekosongan, tidak ada satupun pengrajin batik Kudus. Pada tahun 2005 Ibu Yuli selaku pelopor batik Kudus kontemporer dan pemilik Muria Batik Kudus kembali memunculkan Batik Kudus sebagai salah satu budaya yang ada di kota Kudus. Berbekal ilmu yang Ibu Yuli dapatkan dari pembinaan pemerintah kota Kudus dan pertemuannya dengan satusatunya pengrajin asli Batik Kudus yang masih bertahan menjadi pembatik bernama Ibu Niamah yang berusia 75 tahun. Dari pertemuan dan pembelajaran tentang batik Kudus yang Ibu Yuli dapatkan, Ibu Yuli kemudian kembali memunculkan batik Kudus dalam usaha batik yang dimiliki oleh Ibu Yuli yakni Muria Batik Kudus untuk kembali memperkenalkan batik Kudus kepada masyarakat. Namun, masih banyak orang yang tidak yakin dengan adanya keberadaan batik Kudus. Batik Kudus masih masih tergolong baru dibandingkan dengan batik lain seperti Batik Lasem, Batik Pekalongan dan Batik Solo.

Sudah lebih dari 20 macam batik tulis yang diproduksi oleh Ibu Yuli, semua batik tulis yang diproduksi oleh Muria Batik Kudus memiliki nilai filosofis, budaya maupun kearifan lokal. Batik tulis yang diproduksi oleh Muria Batik Kudus ini mengangkat kebudayaan dan filosofis kearifan lokal seperti motif buah parijoto, motif merak katlea, beras tumpah, cengkehan, kapal kandas, pakis haji, cerita rakyat bulusan dan kretek. Semua produk batik tersebut merupakan batik eksklusif yang diproduksi oleh Muria Batik Kudus. Harga batik eksklusif ini berkisar antara 1-4 juta rupiah untuk setiap satuan batik Muria Kudus. Harga tersebut sebanding dengan kualitas produk yang baik dan proses pembuatan batik yang memakan waktu yang lama pada batik yang dijual oleh Muria Batik Kudus.

Batik Kudus yang diproduksi oleh Muria Batik Kudus merupakan batik dengan pemilihan bahan yang berkualitas. Segmentasi dari Muria Batik Kudus ini adalah untuk kalangan atas. Segmentasi dari Muria Batik Kudus merupakan kalangan atas, namun pengemasan batik yang eksklusif ini tidak dibarengi dengan pengemasan yang menunjukkan nilai dan kualitasnya. Kemasan yang dipakai saat ini berupa kemasan plastik sebagai primary packaging dan tas kertas sebagai secondary packaging Muria Batik Kudus. 


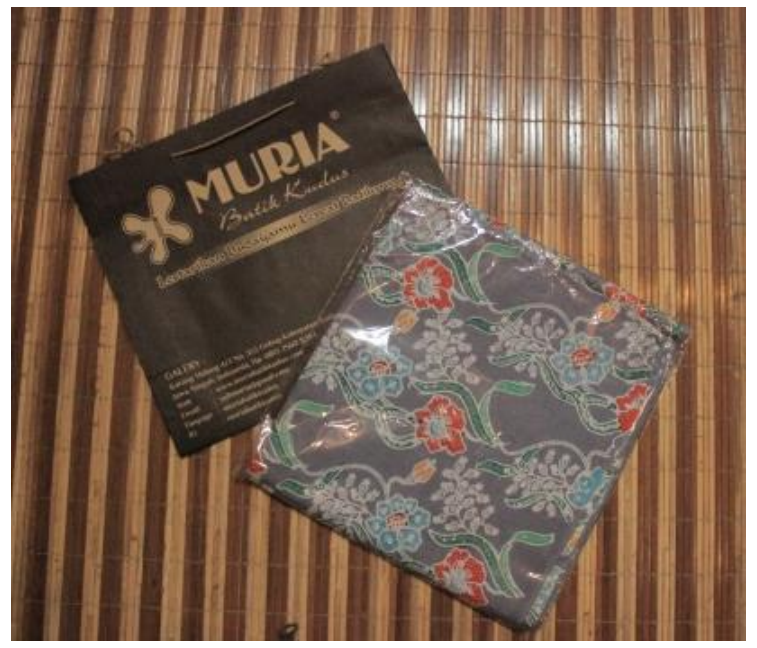

Gambar 3. Kemasan Muria Batik Kudus

[Sumber: Dokumentasi Penulis]

Selama ini Muria Batik Kudus mengikuti acara pameran-pameran baik di dalam kota Kudus maupun di luar kota Kudus untuk memperkenalkan batik Kudus kepada masyarakat. Batik yang diproduksi Ibu Yuli ini terbagi menjadi dua macam yakni batik klasik dengan kualitas premium dan batik biasa. Kemasan yang selama ini ada hanya untuk batik yang biasa, dan tidak untuk batik kualitas premium. Ibu Yuli berkeinginan untuk memperkenalkan eksklusivitas produknya dan nilai filosofis setiap kain batik premium supaya masyarakat luas mengerti akan adanya batik Kudus diantara batikbatik Indonesia yang lain. Muria Batik Kudus membutuhkan desain kemasan yang merepresentasikan eksklusivitas produk dan media pendukung untuk memperkenalkan ragam motif dan nilai filosofis yang terkandung dalam Muria Batik Kudus.

\subsection{Tahap Analisis Data}

Tahap kedua yaitu tahap analisis data verbal dan data visual, dalam tahapan ini menganalisis dan menentukan karakteristik yang akan dituangkan pada kemasan. Pada analisis ini didapatkan bahwa kemasan yang ada sekarang belum bisa menunjukkan nilai eksklusivitas produk dan nilai-nilai filosofis yang terkandung dalam Muria Batik belum diketahui oleh masyarakat. Analisis data lebih mengarah kepada penarikan kesimpulan tentang masalah yang ada yaitu tentang penyampaian citra eksklusif produk batik dan pengenalan tentang motif-motif yang ada pada Muria Batik Kudus. Budaya belanja online yang makin berkembang menuntut Muria Batik Kudus untuk meredesain kemasannya.

\subsection{Tahap Perancangan}

Tahap ketiga yaitu tahap perancangan. Pada tahapan perancangan ini, akan dilakukan pemetaan analisis yang sudah dibuat untuk menjadi dasar proses brainstorming konsep kemasan. Konsep yang dipilih adalah desain kemasan yang menampilkan ciri khas Kudus secara visual sederhana dan elegan. Kemasan yang dibuat merupakan primary packaging. Tujuan dari kemasan yang dipadukan dengan magnetik adalah 
untuk membuat image eksklusif pada kemasan. Dalam tahapan perancangan ini terbagi menjadi tiga bagian yakni perancangan pattern pada kemasan, perancangan kemasan dan perancangan katalog sebagai pendukung dari kemasan Muria Batik Kudus serta hasil dari perancangan kemasan dan katalog.

Desain yang dibuat menggunakan ilustrasi dari salah satu motif Muria batik yakni motif kretek, ilustrasi yang dibuat merupakan ilustrasi daun cengkeh dan tembakau yang disusun berepetisi untuk menimbulkan keseimbangan dalam pola desain. Pemilihan ilustrasi ini dipilih sebagai image baru dari batik Muria Batik Kudus. Pemilihan warna sebagai image yang ada dalam kemasan yaitu dominasi warna coklat untuk merepresentasikan sesuatu hal yang berhubungan dengan alam, warna coklat merupakan warna yang berasosiasi dengan warna natural dan warna coklat melambangkan kearifan, dan menimbulkan kesan klasik pada kemasannya.

Alur perancangan motif ini terbagi menjadi beberapa tahapan. Diawali dengan stilasi visual tembakau dan cengkeh, coloring, pembuatan pattern. Alur perancangan motif dapat dilihat pada Gambar 4.

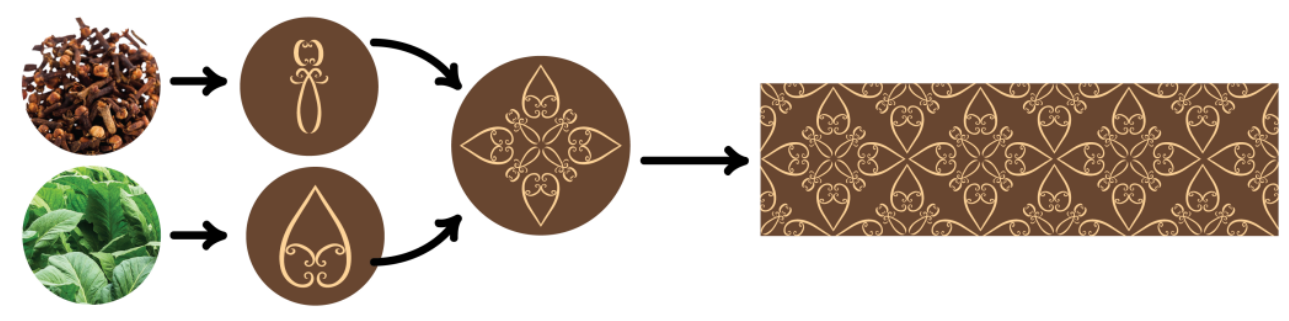

Gambar 4. Alur Perancangan Motif Kemasan [Sumber: Dokumentasi Penulis]

Pada tahapan ini konsep yang telah dibuat akan diterapkan pada perancangan kemasan, penerapan konsep kemasan baik dari segi bahan, ukuran, sampai konten grafis yang terkandung dalam kemasan. Pada perancangan ini lebih mengarah ke layout kemasan secara keseluruhan. Dari pola kemasan batik, layout katalog untuk pendukung kemasan dan pola kemasan untuk pengiriman. Perancangan ini merupakan bentuk terjemahan dari konsep.

Tahapan selanjutnya adalah pembuatan sketsa pola kemasan Muria Batik Kudus. Perancangan kemasan ini berbentuk box magnetik yang bisa langsung dibawa karena sesuai konsep awal kemasan yang menggunakan primary packaging. Kemasan ini berukuran dengan panjang $30 \mathrm{~cm}$, lebar $18 \mathrm{~cm}$ dan tinggi $4 \mathrm{~cm}$. Sketsa pola kemasan ini menjelaskan gambaran tentang tata letak motif, logo, konten grafis dan letak magnet pada kemasan. Perancangan pola kemasan dapat dilihat pada gambar 5 . 


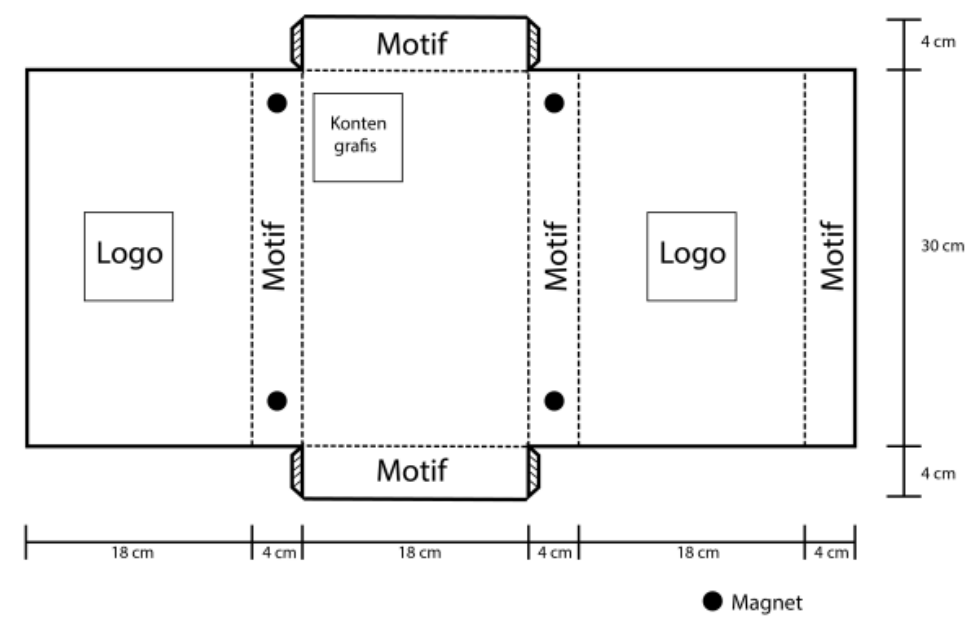

Gambar 5. Perancangan Pola Kemasan Muria Batik [Sumber: Dokumentasi Penulis]

Selain kemasan primer juga dirancang kemasan untuk pengiriman. Perancangan kemasan tersebut sebagai penunjang dari kemasan utama untuk memenuhi kebutuhan pasar online. Box corrugated ini memiliki ukuran dengan panjang $34 \mathrm{~cm}$, lebar $22 \mathrm{~cm}$ dan lebar $5 \mathrm{~cm}$. Perancangan pola kemasan pengiriman dapat dilihat pada gambar 6.

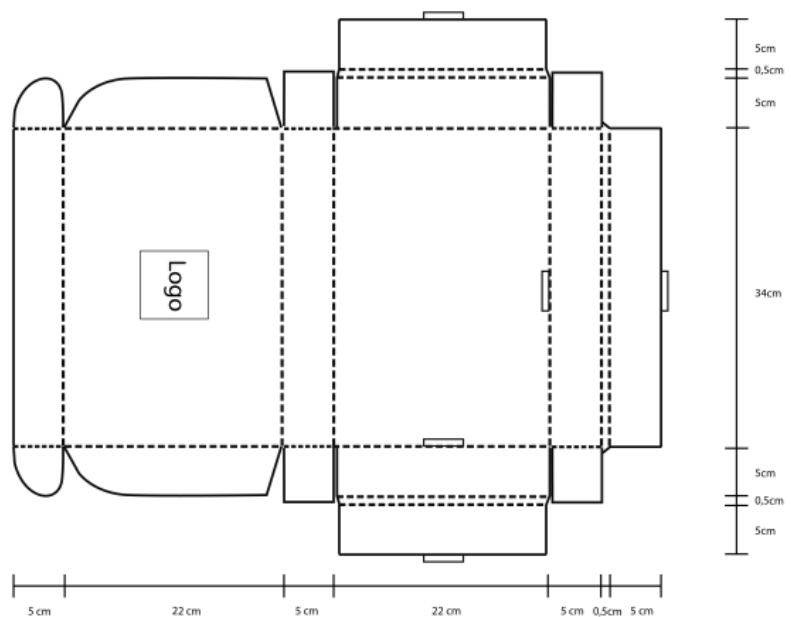

Gambar 6. Pola Kemasan Pengiriman [Sumber: Dokumentasi Penulis]

Tahap selanjutnya adalah coloring dan penempatan logo pada pola kemasan Muria Batik Kudus. Warna yang mendominasi adalah warna coklat yang merepresentasikan warna yang memiliki kearifan dan warna yang mewakili warna natural dari cengkeh dan tembakau yang menjadi pattern pada kemasan Muria Batik Kudus. Kemasan ini dibuat dengan yellow board yang dilapisi oleh kertas ivory yang dilaminasi doff dengan finishing spot uv varnish. Perancangan warna pada pola kemasan dapat dilihat pada gambar 7. 


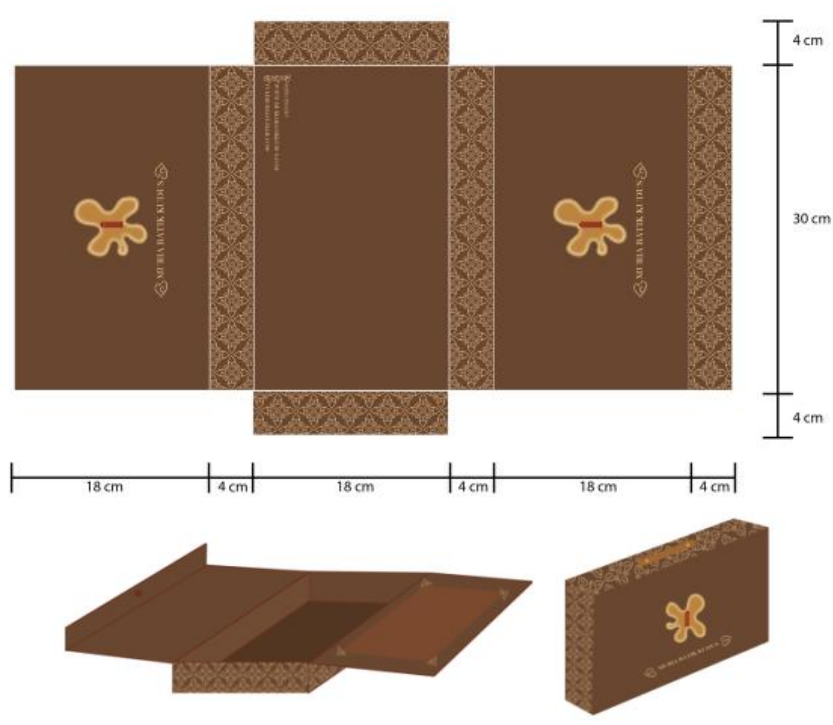

Gambar 7. Perancangan Pewarnaan Pada Pola Kemasan Batik [Sumber: Dokumentasi Penulis]

Pada tahapan ini, kemasan pengiriman menggunakan dominasi warna coklat untuk menyelaraskan dengan kemasan batik. Logo pada kemasan pengiriman dicetak dengan teknik sablon. Perancangan pewarnaan pada pola kemasan pengiriman dapat dilihat pada gambar 8.

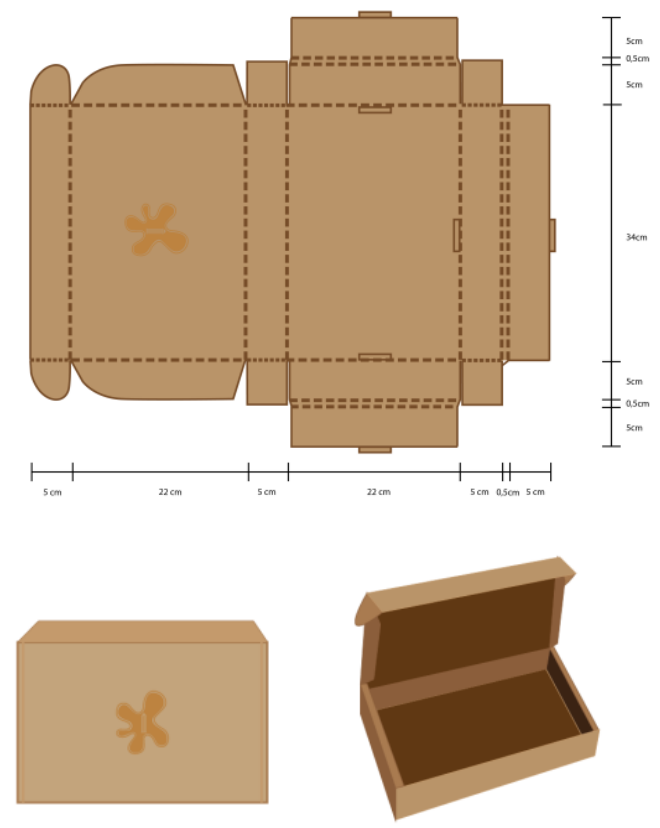

Gambar 8. Perancangan Pewarnaan Pada Pola Kemasan Pengiriman

[Sumber: Dokumentasi Penulis]

Kemasan Muria Batik Kudus ini didukung dengan katalog sebagai media pendukung kemasan. Katalog pada kemasan berisi tentang ragam motif batik yang diproduksi oleh Muria Batik Kudus. Setiap halaman pada katalog berisi tentang gambar motif batik beserta filosofi atau cerita mengenai motif tersebut. Perancangan katalog ini 
berukuran $14 \times 21 \mathrm{~cm}$. Warna yang digunakan dalam katalog menggunakan warna coklat. Tipografi yang digunakan adalah jenis Serif yaitu Monotype Corsiva karena font ini memberikan kesan yang nyaman saat dibaca dan memiliki kesan yang formal. Katalog ini menggunakan dua bahasa, yakni bahasa Indonesia dan bahasa Inggris untuk mempermudah pemahaman konsumen dari Muria Batik Kudus. Katalog ini dibuat dengan ukuran yang tidak terlalu besar untuk memudahkan pemilik katalog menyimpan katalog kedalam kemasan kembali.
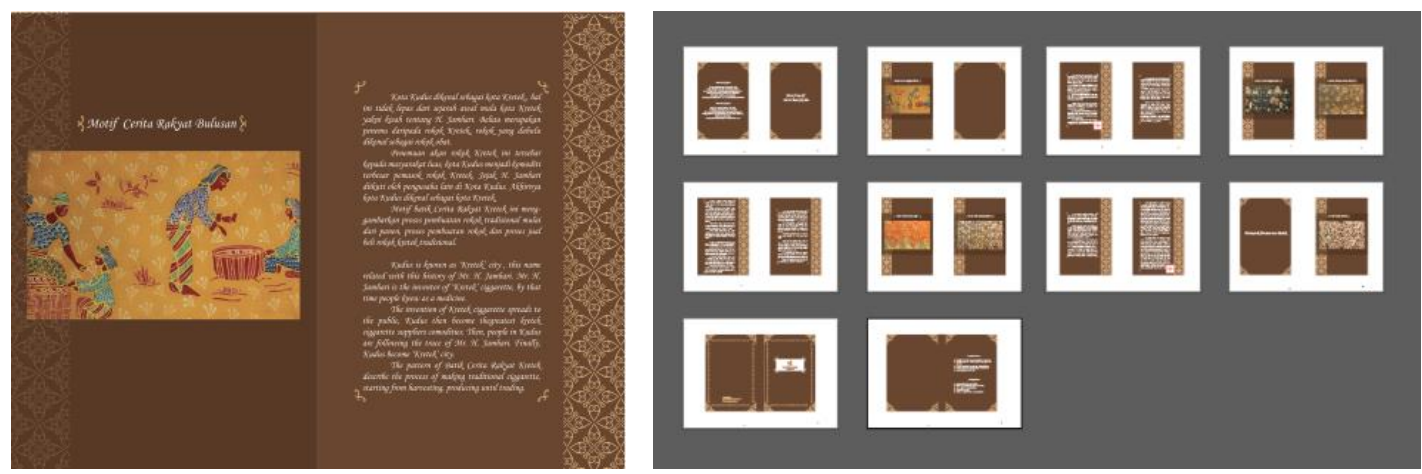

Gambar 9. Desain katalog Muria Batik Kudus

[Sumber: Dokumentasi Penulis]

\section{Label}

Label pada kemasan ini diletakkan melekat pada kain batik Muria Batik Kudus. Label kemasan memuat logo, dan pattern kemasan. Label kemasan berukuran 42x7 cm dan bahan yang digunakan adalah kertas ivory yang dilaminasi doff. Gambar label kemasan dapat dilihat pada gambar 10 .

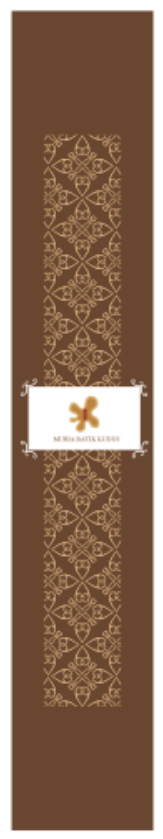

Gambar 10. Label Kemasan [Sumber: Dokumentasi Penulis] 


\section{Label pengiriman}

Label pengiriman ini diletakkan diluar pengemasan pengiriman yang telah dilapisi oleh plastik bubble warp. Label pengiriman memuat logo, pattern kemasan dan kolom keterangan yang memuat informasi penerima, alamat penerima dan informasi contact person dari Muria Batik Kudus. Label pengiriman berukuran $12 \times 12 \mathrm{~cm}$. Bahan yang digunakan merupakan kertas stiker cromo. Gambar label pengiriman dapat dilihat pada gambar 11 .

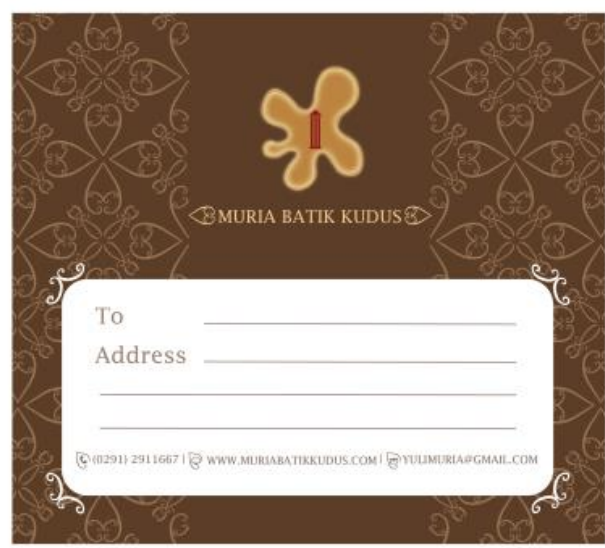

Gambar 11. Label Pengiriman

[Sumber: Dokumentasi Penulis]

Berikut merupakan hasil perancangan kemasan Muria Batik Kudus menerapkan konsep yang sederhana pada setiap kemasan baik kemasan produk maupun kemasan untuk pengiriman dan desain pada katalog Muria Batik Kudus sebagai media penunjang dari kemasan. Motif yang terdapat dalam kemasan produk maupun katalog merupakan motif yang mewakili Muria Batik Kudus dan salah satu kearifan lokal kota Kudus yaitu motif Kretek.

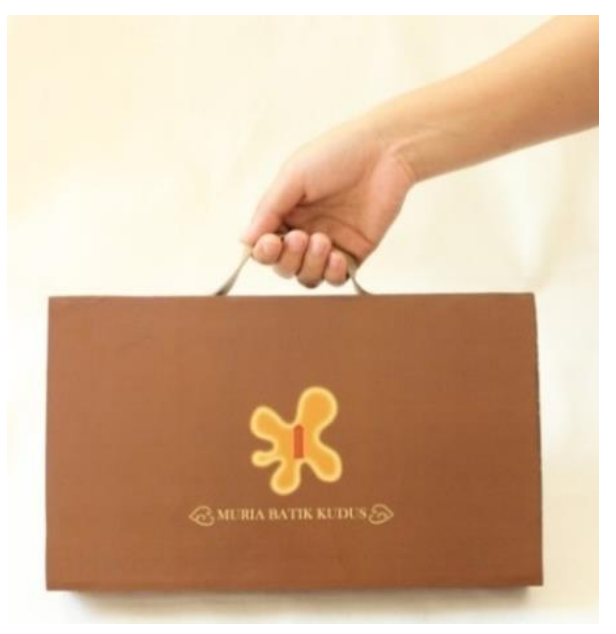

Gambar 12. Kemasan Produk Muria Batik Kudus

[Sumber: Dokumentasi Penulis] 
Kemasan produk menggunakan primary packaging. Penggunaan bahan untuk kemasan yakni hard box dan magnetik adalah untuk menambahkan kesan eksklusif pada kemasan Muria Batik Kudus. Alur pembukaan kemasan didesain dengan sederhana untuk memudahkan konsumen dalam proses pembukaan kemasan.
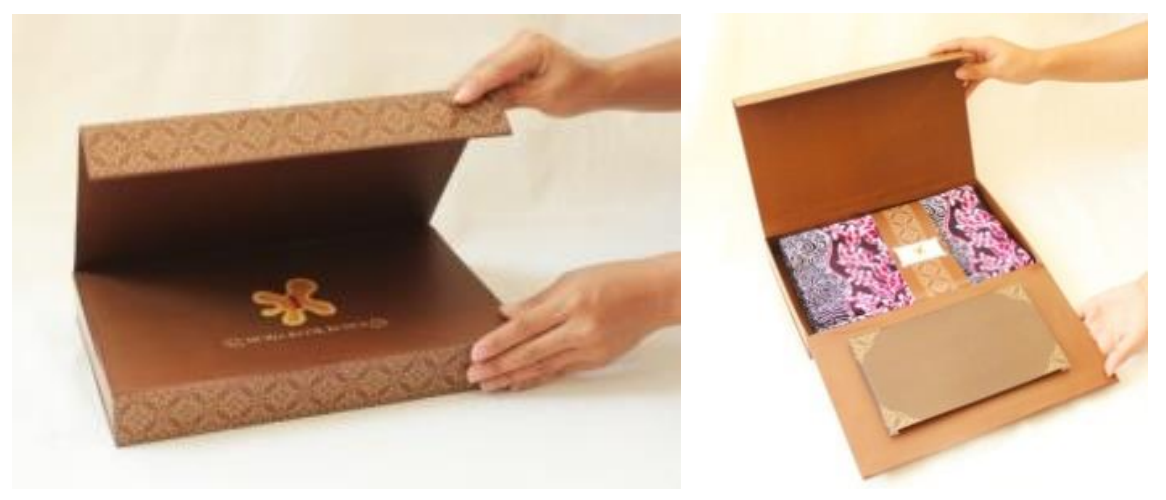

Gambar 13. Alur Pembukaan Kemasan Muria Batik Kudus [Sumber: Dokumentasi Penulis]

Kemasan Muria Batik juga dilengkapi oleh label yang melekat pada produk batik. Label ini difungsikan sebagai penahan agar kain batik tetap tertata dengan baik. Label batik dapat dilihat pada gambar 14 .

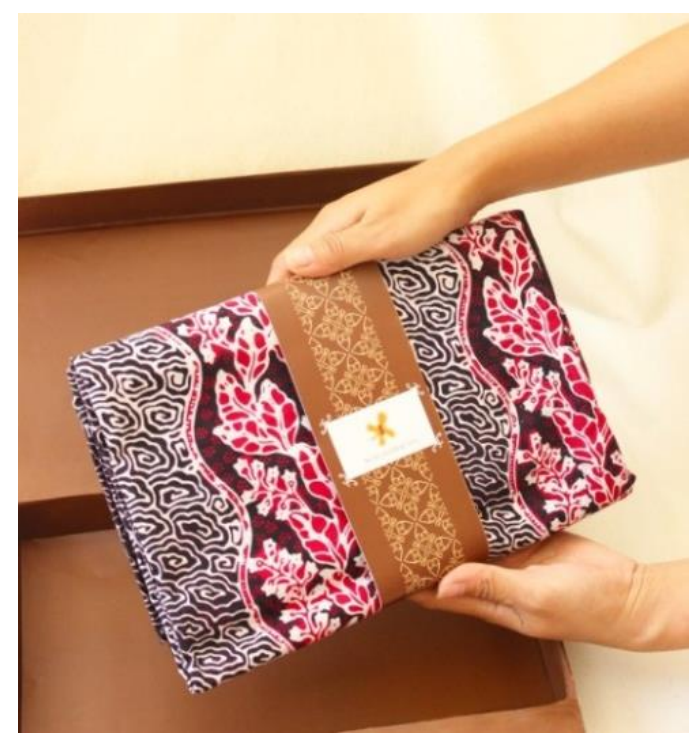

Gambar 14. Label Muria Batik Kudus

[Sumber: Dokumentasi Penulis]

\section{Kemasan Pengiriman}

Kemasan pengiriman ini berfungsi sebagai kemasan pelindung kemasan produk untuk memenuhi kebutuhan pasar online. Bahan yang digunakan dalam kemasan pengiriman adalah corrugated carton dan plastik bubble wrap sebagai kemasan pelindung. Pemilihan kedua bahan ini adalah untuk meminimalisasi kerusakan pada kemasan saat proses pengiriman. Kemasan pengiriman ini disertai dengan label yang berisi tentang 
logo muria Batik, keterangan penerima, alamat penerima dan informasi tentang Muria Batik Kudus.
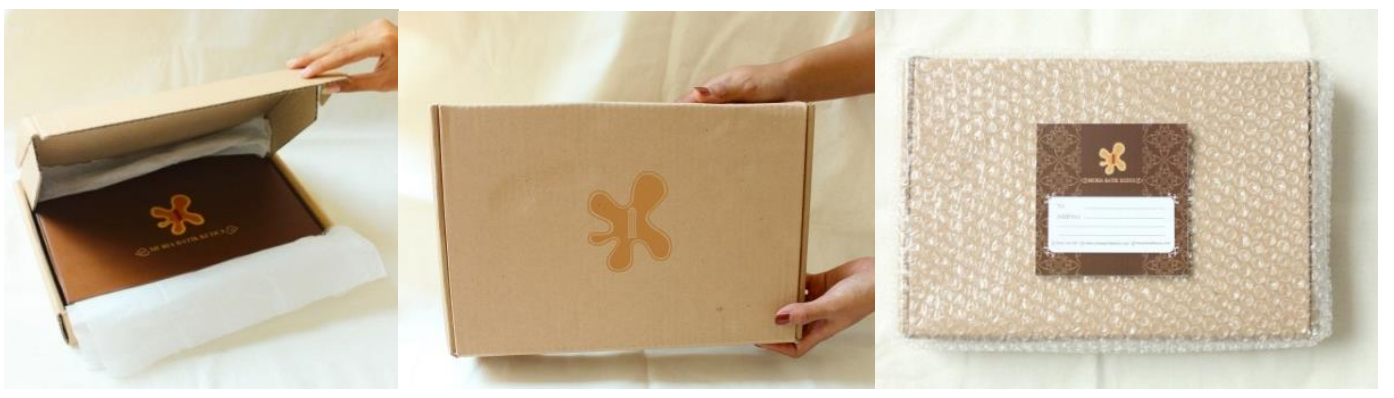

Gambar 15. Kemasan Pengiriman

[Sumber: Dokumentasi Penulis]

\section{Katalog}

Media katalog ini adalah media penunjang kemasan Muria Batik Kudus. Dalam katalog ini berisi informasi tentang sejarah singkat berdirinya Muria Batik Kudus, motif-motif yang ada dalam Muria Batik Kudus dan cara perawatan batik dengan benar. Katalog ini merupakan katalog bilingual, terdapat dua bahasa yakni bahasa Indonesia dan bahasa Inggris.

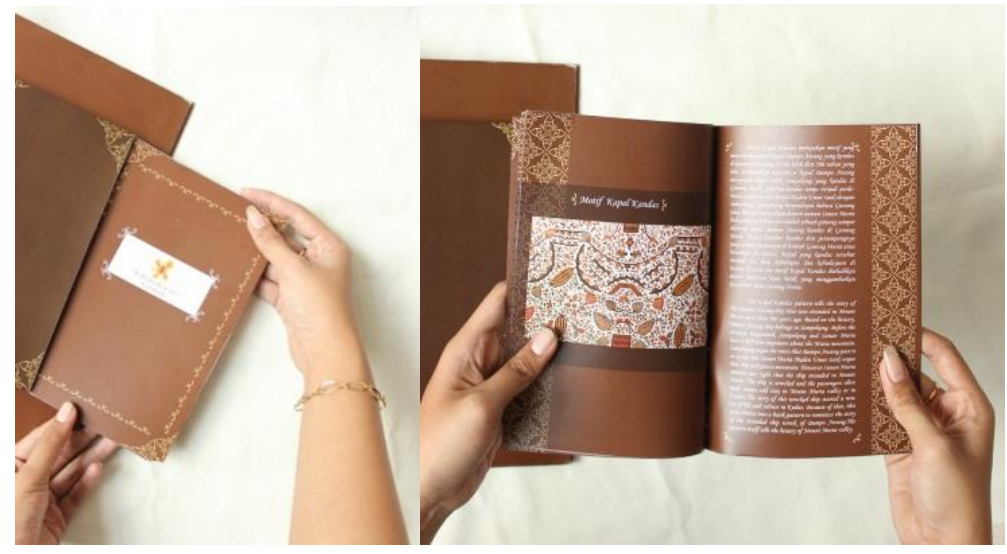

Gambar 16. Katalog Kemasan Muria Batik Kudus

[Sumber: Dokumentasi Penulis]

\subsection{Tahap Pengujian}

Tahapan pengujian dilakukan kepada pemilik Batik, kepada seorang desainer kemasan dan desain grafis serta kepada konsumen dari Muria Batik Kudus. Pada pengujian ini dilakukan secara kualitatif dengan wawancara kepada pemilik Muria Batik Kudus, seorang desainer kemasan dan kepada 5 orang responden selaku target konsumen dari Muria Batik Kudus. Pengujian pertama dilakukan kepada Ibu Yuli Astuti selaku pemilik Muria Batik Kudus. Materi yang diujikan kepada Ibu Yuli Astuti mengenai desain kemasan produk, kemasan pengiriman dan motif yang ada pada kemasan, maupun konten-konten grafis yang ada pada kemasan serta konten yang terdapat pada katalog mengenai kesesuaian gambar motif dengan penjelasannya. Dari pengujian kepada lbu 
Yuli Astuti didapatkan bahwa kemasan sudah sesuai dengan kebutuhan Muria Batik Kudus. Desain kemasan, baik warna, motif sudah sesuai dengan Muria Batik Kudus. Keseluruhan kemasan dari kemasan produk, kemasan pengiriman yang membantu keamanan produk dan memenuhi permintaan belanja online, baik dari segi pemilihan bahan maupun pengemasan produk. Katalog yang terdapat pada kemasan juga membantu Muria Batik Kudus, untuk penerapannya Ibu Yuli Astuti ingin menjadikan kemasan ini menjadi kemasan batik eksklusif Muria Batik Kudus.

Pengujian kedua dilakukan kepada narasumber di bidang kemasan dan desain grafis yaitu Bapak Rony Setyawan dari Eezy.Inc, mengenai desain dan kemasan produk yang telah dibuat. Dari wawancara dapat disimpulkan bahwa kemasan yang dibuat sudah mewakili jiwa yang matang dari target audiens baik pemilihan warna dan motif yang ada sudah mewakili kekhasan lokal dari batik Kudus dan memberikan value dalam kemasan batik yang diangkat. Kemasan pengiriman untuk melindungi produk Muria Batik Kudus dengan pemilihan bahan yang sesuai untuk pengiriman.

Pengujian ketiga dilakukan wawancara kepada 5 orang responden dengan target konsumen umur 30-50 tahun dengan status ekonomi kalangan atas. Didapatkan hasil dari 3 orang yang sudah pernah berbelanja di Muria Batik Kudus memandang peningkatan eksklusivitas produk batik melalui kemasan dan mengerti tentang kebudayaan yang ada di kota Kudus melalui katalog sebagai media pendukung yang terdapat di kemasan. Dari 2 orang dari luar kota Kudus yang belum pernah berbelanja di Muria Batik Kudus didapatkan hasil responden bisa mengerti eksklusivitas produk batik melalui kemasan dan mengerti budaya yang ada di kota Kudus melalui katalog yang ada dalam kemasan. Dari 5 orang responden tersebut didapatkan hasil bahwa secara keseluruhan kemasan Muria Batik baik kemasan produk, maupun kemasan pengiriman sudah sesuai dengan kebutuhan dengan pemilihan bahan yang baik untuk kemasan produk maupun kemasan pengiriman.

\section{KESIMPULAN}

Setelah batik Kudus sempat menghilang dari kota Kudus, brand Muria Batik Kudus kembali memunculkan ragam batik Kudus dengan motif-motif kebudayaan di kota Kudus. Perancangan kemasan Muria Batik Kudus adalah untuk menguatkan citra eksklusif dan kebutuhan distribusi produk, perancangan ini dilengkapi dengan katalog yang berisi sejarah singkat tentang Muria Batik Kudus dan motif-motif tentang kebudayaan lokal kota Kudus. Dari pengujian kemasan Muria Batik yang baru kepada pemilik, desainer kemasan dan konsumen dari Muria Batik, didapatkan hasil bahwa perancangan kemasan baru dari Muria Batik ini memberikan citra eksklusif pada produk serta memenuhi kebutuhan distribusi produk Muria Batik Kudus. Katalog yang terdapat dalam kemasan memudahkan para konsumennya untuk mengenal lebih dalam tentang kebudayaan-kebudayaan lokal kota Kudus yang tertuang dalam katalog. Dalam katalog yang berisi sejarah singkat tentang Muria Batik Kudus, motif-motif batik tulis klasik yang menggambarkan kebudayaan lokal kota Kudus dan cara perawatan batik tulis. Penyajian katalog menggunakan bahasa Indonesia dan bahasa Inggris, 
untuk memudahkan konsumen dari Muria Batik Kudus untuk mengenal kebudayaan lokal yang terdapat pada motif-motif Muria Batik Kudus.

Penelitian ini dapat menjadi media bagi pihak Muria Batik Kudus untuk menguatkan citra eksklusif dari produk-produk batik yang dihasilkan oleh Muria Batik Kudus. Adapun saran untuk menambahkan tentang konten katalog mengenai cara penyimpanan batik agar menjadikan katalog semakin lebih baik.

\section{DAFTAR PUSTAKA}

Crisnawati. 2013. Perancangan Desain Kemasan Kerajinan Di "Ria Batik" Solo sebagai cinderamata Khas dari Kota Solo. Jurnal DKV Adhiwarna. Vol.1 No. 2. Jurnal Universitas Kristen Petra: Surabaya.

Rahardjo, S. T., \& Pramusita, R. D. 2016. Tinjauan Tampilan Visual Desain Kemasan Roti Murni di Yogyakarta. ANDHARUPA: Jurnal Desain Komunikasi Visual \& Multimedia, 2(02), 103-120.

Edris, Mohammad. 2016. UMKM Kudus di Era MEA. (Updated 19 Januari 2016) URL: http://www.umk.ac.id/index.php/tajug-readmore/1700-umkm-kudus-di-eramea [Diakses pada tanggal 6 Desember 2016]

Kotler dan Keller. 2009. Manajemen Pemasaran Jilid I. Edisi ke 13. Jakarta: Erlangga.

Ratnasari, Rochana, dkk. 2012. Penyuluhan Budaya Sebagai Upaya Pengembangan Industri Kreatif Berbasis Kearifan Lokal. Universitas Lampung: Bandar Lampung.

Sarwono, Jonathan, dan Hary Lubis. 2007. Metode Riset Untuk Desain Komunikasi Visual. Edisi I. Yogyakarta: C.V Andi Offset.

Wulandari, Ari. 2011. Batik Nusantara. Edisi I. Yogyakarta: CV. Andi Offset. 